\title{
THE MANCHESTER REGION
}

Manchester and its Region

(A Survey prepared for the British Association.) Pp. xviii $+265+29$ plates. (Manchester: The University Press, 1962. Published for the British Association.) 30s. net.

$\mathrm{T}$ can be said that the objectives of the annual meeting of the British Association for the Advancement of Science are essentially two-fold. The first is to present science in all its broadest fields to the world. The second is that the region in which the meeting is being held be given an opportunity to present itself. This second objective is made simpler if there is a means of gaining a preview of the area, and the more specialized knowledge gleaned at the addresses and excursions can be better appreciated. It was, in part, for this purpose that the survey Manchester and its Region was prepared. The result fulfils all in an admirable fashion and offers a most interesting and permanent record of Manchester up to 1962. The book of the survey consists of nineteen well-illustrated chapters prepared by thirty-three contributors, who are drawn mainly from the University of Manchester. There are also contributions from the Manchester Museum, the Civil Service and the Shirley Institute.

For the geographer visiting the region not only are the landscapes of 'Lancastria' ably described (the author here takes great care to define all technical terms used), but also excellent chapters have been prepared on the climate and the Manchester conurbation. Geologists are provided with a thirteen-page introduction to the area which is illustrated with bold maps styled after those presented by the Geological Survey of Great Britain in its Regional Handbooks. However, the authors of this chapter concentrate essentially on the geological history of the region, and, rather disappointingly, dismiss the 'structures' involved in just more than a page. For the botanist there is a chapter on "Interesting Features of the Local Vegetation and Flora", and here, on a very general ecological basis, the authors have chosen to describe only those features which they feel merit particular attention by the visitor. On the other hand, the fauna of the region is systematically described according to the various major classes represented. (An ample list of books for further reading is provided at the end of this chapter.)

Historians, including archæologists, are fortunate in that three chapters have been contributed. The first deals with Roman Manchester, the second with medieval and early modern Manchester, while the third covers "The Birth of Modern Manchester". Economists wishing to gain an insight into the structure of industry in Lancashire will find an interesting chapter which tackles such subjects as changes in population and the effects on industry, employment, the balance of industry and the location of growth industries. "Land Utilization and Agriculture in the North-West" describes such aspects as forest and woodland resources, urban development and other land uses, localized types of farming, the economic conditions of farming and the level of farm incomes. Those who take an interest in sociology will gain a good introduction from the chapter entitled "Social Statistics and Social Conditions of Greater Manchester". However, the authors are only able to deal in detail with tho information that accrued from the Census, England and Wales, 19.51, as only the preliminary results of the Census of 1961 have so far been issued.

Chapters 13-17 deal with the part that Manchester has played in the advancement of science, medicine, education (two chapters) and sociology, and this section of the book makes excellent general reading. For example, "The History of Science in Manchester" outlines the parts played in the rise of science and the Industrial Revolution by such scientists and engineers as Dalton, Frankland, Roscoe, Joule, Balfour Stewart, J. J. Thomson, Poynting, Rutherford, Schuster, Fairbairn, Whitworth, Osborne Reynolds, etc. This is indeed a formidable list on any account, and from this chapter one realizes the great debt that the world of science owes to such institutions as the Manchester Literary and Philosophical Society, Owens College, the Victoria University (of which the aforementioned was a constituent college) and the Manchester College of Science and Technology. The chapter dealing with Manchester's place in the history of medicine outlines the origins of the Medical School and systematically accounts for the work of such eminent people as White, Ferriar, Percival, Roberts. Whitehead, Jefferson, Dreschfold, Barclay, Legge, Elliot Smith, Raper, etc., to mention but a few. This chapter deals with, as the author states, only those "who are no longer with us". Indeed, had the work of living medical men been included very much more space would have been required. The remaining three chapters of this 'section' are entitled, "Manchester and the Supply of Schools", "Adult Education in the Manchester Area" and "Some Social Pioneers".

The last two chapters of the book present the hopes for the future. Chapter 18 is entitled "The University of the Future", and Chapter 19 "Planning the City of the Future". These again make good general reading, but even more so for those who are participating in the 1962 Meeting of the British Association, who will be gaining much local knowledge and interest. Through this they will be equipped to judge for themselves the value of the development plans by which Manchester and its region can continue to play its part as one of the greatest industrial, commercial and cultural centres of the world.

The Local Committee who organized the survey and Prof. C. F. Carter, who edited the book, and his team of contributors are to be commended for the excellent way in which they have presented Manchester and its Region. So far as can be seen there are only two things that could possibly have improved it. The first is that not all chapters have lists of further recommended reading, and the second that a general index is not provided. 


\section{(Continued from page 874)}

adding 2 volumes of cold ethanol; the precipitate is washed and redissolved in $0.2 \mathrm{M}$ phosphate buffer $p \mathrm{H} 7 \cdot 0$. Alternatively, bentonite, prepared by the procedure of Fraenkel-Conrat et al. ${ }^{5}$ is used instead of nickel ions. Preparations are titrated by the plaque technique described by Montagnier and Sanders ${ }^{6}$. When we repeated the experiment of Huppert and Sanders using these methods of preparing RNA, that prepared from the virus deposit was ten times as infective as that prepared from the supernatant (Table 1); the infectivity of the RNA preparations was abolished in $15 \mathrm{~min}$ at $37^{\circ} \mathrm{C}$ by $2 \mu \mathrm{g} / \mathrm{ml}$. of ribonuclease. This experiment was repeated four times with the same result, which was not affected by the method of assay of infective RNA (Table 2). However, when the original method of extraction of Huppert and Sanders was substituted for the new method, the virus deposit again gave less infective RNA than the supernatant (Table 3). The loss of RNA titre in the deposit was thus due to the method used to prepare the RNA, and not to the infectivity assay.

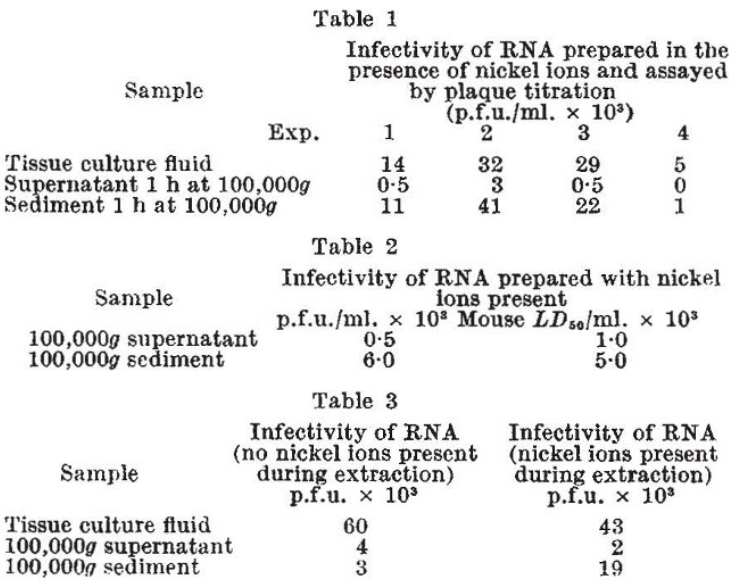

These results show that it is in fact possible to prepare infective RNA from EMC virus by extraction with cold phenol. Earlier ${ }^{3}$, it was suggested that virus, unlike the 'infective RNA component', was resistant to the action of cold phenol by virtue of the protective protein capsid, but might bo susceptible to the action of hot phenol as is ME virus?. Since infective RNA can now be obtained from virus using cold phenol, we looked for an increased yield of RNA infectivity with hot phenol, but found none; the susceptibility of both virus and infected cells to hot and cold phenol appears to be the same (Table 4). The reason for the original failure ${ }^{1}$ to obtain infective material from the virus deposit was that the technique then used failed to inhibit traces of ribonuclease present in the final preparation, and that the enzyme destroyed the infectivity before it could be detected. That this may be so is shown in Table 3, where the main difference between the columns is the low infectivity of RNA prepared by the old technique from the centrifuge doposit. Preliminary results using the method described by Houck ${ }^{8}$ showed that such deposits may contain more ribonuclease than the supernatants. Moreover, there was evidence that the tissue culture fluid and $100,000 \mathrm{~g}$ supernatants contained an inhibitor of ribonuclease action which may protect the ribonucleic acid obtained from the virus in these preparations.

$$
\text { Table } 4
$$

Infectivity

$\begin{array}{lcc}\text { Infectivity of RNA } & \begin{array}{c}\text { Infectivity of RNA } \\ \text { obtained by cold phenol } \\ \left(4^{\circ} \mathrm{C}\right) \text { extraction; } \\ \text { nickel ions present } \\ \text { during preparation }\end{array} & \begin{array}{c}\text { obtained by hot phenol } \\ \left(50^{\circ} \mathrm{C}\right) \text { extraction; } \\ \text { nickel ions present } \\ \text { during preparation }\end{array} \\ \begin{array}{lcc}\text { PFU } \times 10^{3} & \text { PFU } \times 10^{3}\end{array} \\ \begin{array}{l}\text { Cells } 5 \text { h after infection } \\ \text { Crude virus }\end{array} & 23 & 13 \\ & 12 & 4\end{array}$

Although there is now no evidence of a small 'ribonucleic acid component' in crude preparations of EMC virus it remains unlikely that virus is the only source of infective nucleic acid in infected cells. There is an eclipse phase during which the infectivity of extracted nucleic acid increases without a concomitant increase in virus titre $^{2}$, the maximum infectivity of RNA is reached about $3 \mathrm{~h}$ before maximum virus titre ${ }^{2}$, and $5 \mu \mathrm{g} / \mathrm{ml}$. of euflavin given at $4 \mathrm{~h}$ after infection supprosses the production of virus without affecting that of infective $\mathrm{RNA}^{2}$. However, our previous conclusions ${ }^{3}$ as to the nature of the RNA component depended on the assumption that cold phenol extracts no infective RNA from virus. and may be incorrect.

${ }^{1}$ Huppert, J., and Sanders, F. K., Nature, 182, 515 (1958).

2 Sanders, F. K., Nature, 185, 802 (1960).

${ }^{3}$ Bellett, A. J. D., and Burness, A. T. H., Nalure, 190, 235 (1961).

'Schuster, H., Schramm, G., and Zilly, W., Z. Naturforsch, 11,b, 339 (1956).

'Fraenkel-Conrat, H., Singer, B., and Tsugita, A., Virology, 14, 5 (1961).

- Montagnier, L, and Sanders, F. K., C.R. Acad. Sci, Paris, 254, 2247 (1962).

Franklin, R. M., Wecker, E., and Henry, C., Virology, 7, 220 (1959). ${ }^{3}$ Houck, J. C., Arch. Biochem. Biophy8., 73, 384 (1958).

\section{POLYMERIZATION OF TRANSITION METAL $\beta$-DIKETONE CHELATES}

\section{By Dr. D. P. GRADDON}

Department of Inorganic Chemistry, University of New South Wales, Sydney

$\mathrm{T}$ HE determination by Bullen, Pauling, and Mason $^{1}$ of the crystal structure of bis-acetylacetonato-nickel(II) showed that this green, paramagnetic compound, long regarded as an example of tetrahedrally 4 : co-ordinated nickel(II), was in fact trimeric, each nickel atom being octahedrally $6: \mathrm{co}$ ordinated(I). That this structure is preserved in non-donor solvents is implied by Cotton and Fackler's observations of the spectra and magnetic properties; they also suggest that at high temperatures equilibrium is established between trimeric and monomeric forms, and observe that only diamagnetic, presumably monomeric and planar, forms occur when bulky substituents obstruct polymerization ${ }^{2,3}$.

The preservation of the trimeric form in hydro. carbon solutions is confirmed by our own observations of the molecular weight in benzene and of the equilibrium of the reaction with $2: 6$-dimethylpyridine in toluen $\Theta^{4}$. Fackler ${ }^{5}$, studying the equilibrium with pyridine, also found the anhydrous compound to be trimeric, though disagreeing with us on the nature of the intermediate addition compound formed. It 